\title{
PENGARUH INTERNET TERHADAP KEBEBASAN SIPIL DI INDONESIA: INTERPRETASI KONSEP GERAKAN SOSIAL DARI MANUEL CASTELLS
}

\author{
Dewi Udhany ${ }^{1}$, Irwansyah ${ }^{2}$ \\ ${ }^{1}$ Program Magister Ilmu Komunikasi, Universitas Pelita Harapan, Jakarta \\ ${ }^{2}$ Program Studi Ilmu Komunikasi, Universitas Indonesia \\ email : dewi.udhany@gmail.com,dr.irwansyah.ma@gmail.com
}

Korespondensi : dr.irwansyah.ma@gmail.com

\begin{abstract}
This study aims to investigate the relationship between the Internet and civil liberties in Indonesia using the social movement dimension of Manuel Castells (2012). This empirical research was conducted in 34 provinces in the period 2015 - 2019. Through multiple linear regression techniques, this study found that there was no significant influence between the Internet and civil freedom. Furthermore, individuals who carry out social movements in Indonesia are educated individuals who have strong ties to civil associations. Contrary to Castells' claim, the unemployed in Indonesia tend not to participate in social movements. In addition, individuals with high levels of trust and happiness will be increasingly involved in social movements. We speculate that individuals in Indonesia do not receive high social support when joining a social group. Also, there is a possibility that someone with a high level of life effectiveness perceives the need for social movement as the lowest.
\end{abstract}

Keywords: internet, social capital, happiness, unemployment, civil freedom, social movements, indonesia

\begin{abstract}
Abstrak
Studi ini bertujuan untuk menyelidiki hubungan antara Internet dan kebebasan sipil di Indonesia dengan menggunakan dimensi gerakan sosial dari Manuel Castells (2012). Penelitian empiris ini dilakukan di 34 provinsi pada periode 2015 - 2019. Melalui teknik regresi liniear berganda, studi ini menemukan bahwa tidak terdapat pengaruh yang signifikan antara Internet dan kebebasan sipil. Lebih lanjut, individu yang melakukan gerakan sosial di Indonesia adalah seseorang terpelajar yang memiliki ikatan yang kuat dengan asosiasi sipil. Berbeda dengan klaim Castells, para penganggur di Indonesia cenderung tidak berpartisipasi dalam gerakan sosial. Di samping itu, individu dengan tingkat kepercayaan dan kebahagiaan yang tinggi akan semakin terlibat dalam gerakan sosial. Kami berspekulasi bahwa individu di Indonesia tidak menerima dukungan sosial yang tinggi ketika bergabung dalam sebuah kelompok sosial. Juga, terdapat kemungkinan apabila seseorang dengan tingkat keefektivitas hidup yang tinggi menganggap kebutuhan akan gerakan sosial sebagai yang terendah.
\end{abstract}

Kata kunci: internet, modal sosial, kebahagiaan, pengangguran, kebebasan sipil, gerakan sosial, indonesia 


\section{PENDAHULUAN}

Fenomena Arab Spring, Gerakan Pendudukan, dan pemberontakan lainnya, yang hampir terjadi bersamaan dari tahun 2010 hingga 2012, memperkuat penilaian banyak pengamat bahwa gerakan sosial telah memasuki era baru (Della Porta \& Mosca, 2005). Dalam pandangan mereka, gerakan sosial semakin dicirikan oleh pengunjuk rasa dari generasi milenial dan berpendidikan tinggi. Gerakan ini kemudian dihubungkan dengan media komunikasi digital yang menuntut adanya otoritas politik dan ekonomi dari para elit di negara masing-masing (Castells, 2012).

Beberapa pengamat mencoba untuk menganalisa hubungan antara optimisme teknologi dan gerakan sosial. Mozorov (2011) menyatakan bahwa media komunikasi digital dapat diawasi dan dikendalikan oleh seseorang yang mempunyai otoritas. Oleh karenanya, hal tersebut dapat membatasi potensi mobilisasi dari Internet. Mereka kemudian mempertanyakan sejauh mana kebebasan sipil melalui aksi protes berbasis digital. Secara spesifik, mereka menganalisa keterlibatan dan partisipasi gerakan online yang terus menerus distratifikasi oleh hak sosio-ekonomi (Oser et al., 2013). Pada akhirnya, kritikus menegaskan bahwa hanya dengan memperhatikan jenis gerakan sosial tertentu, optimisme teknologi dapat mengalihkan perhatian ke sejauh mana konteks nasional dapat berlanjut mempengaruhi partisipasi masyarakat (Farrell, 2012; Zhang \& Brym, 2019).

Di Indonesia, Badan Pusat Statistik (BPS) mencoba untuk mengukur kebebasan sipil dalam indeks demokrasi. Capaian indikator ini tidak hanya rendah pada tahun 2019, namun juga secara konsisten rendah dalam 5 tahun terakhir. Jika ditelaah lebih lanjut, aspek kebebasan berserikat dan berkumpul mengalami penurunan 4,32 poin dari tahun 2018 menjadi 78,03 poin pada tahun 2019. Aspekaspek lainnya seperti kebebasan berpendapat juga mengalami penurunan 1,88 poin dari tahun 2018 menjadi 84,29 poin pada tahun 2019. Hasil penelitian dari BPS ini mengindikasikan bahwa ancaman dan penggunaan kekerasan oleh aparat pemerintah yang menghambat kebebasan masyarakat untuk berserikat, berkumpul, dan berpendapat masing sering terjadi.

Didasari pada tren kebebasan sipil di Indonesia, peran Internet pada aktivisme digital dalam membentuk gerakan sosial menjadi sangatlah penting. Pemikiran Castells (2012) yang tertuang dalam Networks of Outrage and Hope: Social Movements in the Internet Age dapat menjadi pintu masuk untuk menjelaskan fenomena ini. Secara umum, ia menjelaskan bahwa kekuatan komunikasi adalah bentuk sentral dari kekuasaan saat ini. Castells juga berpendapat bahwa Internet memungkinkan pembangunan otonomi komunikatif. Disamping, Internet dapat membentuk gerakan jaringan sosial yang bersifat kontemporer (online dan offline) untuk mengkomunikasikan dan mengalihkan emosi kolektif dari kemarahan dan harapan menjadi tindakan kolektif (collective action).

Mengacu pada latar belakang masalah, artikel ini bertujuan untuk mengelaborasi sejauhmana Internet berpengaruh pada kebebasan sipil di Indonesia. Mengingat keterbatasan data sekunder dari BPS untuk melakukan studi kuantitatif lintas provinsi di Indonesia, penulis hanya membatasi penelitian pada beberapa aspek kunci dari teori perkembangan gerakan sosial yang digagas oleh Manuel Castells (2012) selama periode 2015 - 2019. Menurut pengamatan kami, tulisan ini 
adalah investigasi pertama yang menyelidiki hubungan empiris antara penggunaan Internet dan kebebasan sipil di 34 provinsi.

\section{Perspektif Gerakan Sosial di Era Digital}

Sampai akhir 1960-an, gerakan sosial sering dianggap sebagai ledakan ketidakpuasan yang emosional, spontan, dan irasional (Hannigan, 1985). Satu dekade kemudian, orientasi ini memberi jalan pada pendekatan strukturalis yang menekankan ketersediaan peluang politik dan akses ke sumber daya sebagai syarat yang diperlukan untuk pembentukan gerakan (McAdam et al., 2009).

Studi tentang gerakan sosial kemudian mengalami pergantian budaya yang ditandai dengan minat baru dalam hubungan antara emosi, budaya, dan aktivisme gerakan sosial (Brym, 2007; Castells, 2012). Menurut pemikiran Castells (2012), pertumbuhan jaringan, yang menyalurkan arus barang dan informasi, dapat memfasilitasi pergeseran dari sektor manufaktur ke sektor ekonomi yang berbasis pengetahuan. Di satu sisi, kondisi ini menyebabkan segala kontroversi di ranah politik yang menyangkut pergulatan atas kontrol dan distribusi sumber daya menjadi tenggelam. Di sisi lain, masyarakat lebih peduli dengan segala hal yang berkaitan dengan moral atau etika (Inglehart, 2018). Reorientasi ini membuat beberapa analis mengklaim bahwa kita sejatinya telah memasuki era baru dalam gerakan sosial (Castells, 2012).

Di era baru ini, teknologi dan komunikasi secara online dapat mempromosikan aktivisme sipil melalui berbagai cara. Kalangan tekno-optimis berpendapat bahwa jaringan digital mampu menyamakan hubungan kekuasaan antara aktivis dan otoritas negara dan elit perusahaan dengan memberi para aktivis alat baru untuk mendistribusikan ide dan memobilisasi kelompok (Della Porta \& Mosca, 2005). Terkait dengan hal tersebut, Castells (2012) menyatakan bahwa komunikasi diri massa (self-mass communication) yang didasarkan pada jaringan horizontal komunikasi yang bersifat interaktif sangat sulit untuk dikendalikan oleh pemerintah atau perusahaan.

Jaringan digital juga menyebabkan orang-orang yang sebelumnya dikecualikan dari aktivisme untuk terlibat dalam gerakan sosial dengan menurunkan biaya komunikasi dan koordinasi (Shirky, 2008). Penyebaran informasi secara digital dapat memobilisasi aktivis secara cepat dan luas. Kondisi ini dapat mempengaruhi taktik dari sebuah gerakan sosial. Menurut Castells (2012), rangkaian demonstrasi di berbagai lokasi terjadi karena pengaruh "penularan" informasi secara digital. Pada akhirnya, mengacu pada rendahnya biaya koordinasi dan cepatnya informasi yang dihasilkan oleh para aktivis yang tersebar di berbagai wilayah geografis, teknologi dan komunikasi secara online dapat meletakkan dasar untuk pengembangan identitas global. Kondisi ini menyebabkan para aktivis melihat diri mereka sebagai anggota komunitas transnasional yang terdiri dari sekumpulan individu dengan pengalaman dan keluhan yang sama (Baek et al., 2012).

Castells (2012) berpendapat bahwa gerakan sosial dapat bersifat global karena aktivis di seluruh dunia dapat terhubung. Aktivis di satu negara dapat belajar dari pengalaman sesama aktivis di negara lain. Mereka sebenarnya sering menggunakan pengalaman tersebut untuk terlibat dalam mobilisasi gerakan sosial di 
negaranya. Selain itu, mereka terus mengekspresikan kebebasan sipil melalui Internet dan media penunjangnya. Seringkali, para aktivis tersebut melakukan rangkaian protes dan unjuk rasa yang bersifat global dalam suatu jejaring sosial pada waktu yang bersamaan. Mereka dapat menyuarakan kesadaran tentang isu dan masalah bagi umat manusia. Terkait dengan hal tersebut, mereka secara jelas menampilkan budaya kosmopolitan sambil berakar pada identitas spesifik yang mereka punyai. Pada batas tertentu, mereka akan menghilangkan perpecahan antara identitas komunal lokal dan jaringan individu global yang terjadi saat ini.

Para tekno-optimis berpendapat bahwa hubungan antara negara dan aktivis saat ini telah bergeser karena adanya berbagai keluhan (grievances) yang disampaikan oleh para aktivis menjadi kurang relevan dengan karakteristik ekonomi dan politik di beberapa negara, seperti tingkat perkembangan ekonomi di suatu negara dan sejauh mana negara tersebut menyediakan saluran demokrasi. Para aktivis lebih menyoroti persoalan yang menjadi perhatian semua umat manusia, seperti meningkatnya ketidaksetaraan yang disebabkan oleh globalisasi, upaya pemerintah untuk mengadopsi langkah-langkah penghematan, penindasan hak asasi manusia, perubahan iklim, serta kurangnya ketahanan pangan (Coyne, 2012). Dari sudut pandang ini, gerakan-gerakan yang dimulai sebagai keluhan dan tantangan yang bersifat lokal dapat menyebar secara lintas negara. Contoh awal adalah gerakan Zapatista Meksiko, yang dimulai pada tahun 1990-an sebagai pemberontakan lokal tetapi segera mendapatkan dukungan internasional melalui penggunaan Internet untuk menghubungkan keluhan lokal dengan perjuangan internasional yang lebih luas melawan globalisasi (Van Laer \& Van Aelst, 2010).

Terlepas dari keunggulan tekno-optimis, pandangan tersebut setidaknya mempunyai dua kelemahan terkait gerakan sosial di era Internet. Pertama, bukti bahwa Internet dapat mempromosikan kebebasan sipil sangatlah beragam (Haunss, 2015). Ketidakmerataan akses pada telepon seluler dan Internet berkecepatan tinggi mengecualikan orang-orang yang paling tidak beruntung untuk terlibat dalam jaringan komunikasi baru dan oleh karenanya, tidak mampu menggerakkan kebebasan sipil secara digital. Kondisi ini mungkin menjadi salah satu alasan mengapa aktivisme online terus dikaitkan dengan keistimewaan sosio-ekonomi, termasuk tingkat pendidikan, pendapatan, dan keterhubungan jaringan yang lebih tinggi (Oser et al., 2013). Lebih lanjut, karena media komunikasi digital diawasi dan dikendalikan oleh seseorang yang mempunyai otoritas, media tersebut sejatinya hanya digunakan untuk menggagalkan aktivisme yang bersifat progresif dan bahkan memobilisasi gerakan kontra, yang tidak hanya berlangsung dalam rezim otoriter tetapi juga dalam rezim demokrasi (Morozov, 2011; Brym et al., 2018).

Disamping itu, media sosial dirancang untuk menjual data pengguna ke bisnis sehingga pebisnis dapat mengidentifikasi individu yang memiliki kemungkinan tertinggi untuk menyukai dan membeli komoditas tertentu. Hasil penyebaran dan intensifikasi dari budaya konsumen dapat digunakan untuk mengalihkan perhatian dari masalah politik dan menurunkan tingkat keterlibatan berbagai pengguna dalam hal politik (Leistert, 2015). Platform media sosial juga mampu menyaring informasi sampai pada batas dimana platform tersebut mampu menarik pengguna untuk lebih menyukai konten yang memperkuat pandangan 
politik mereka. Karena platform ini tidak memeriksa informasi yang beredar secara online, beberapa berita yang ditemukan pengguna kemungkinan besar palsu atau menyesatkan. Ketika satu pengguna berbagi informasi yang salah di jejaring online yang terdiri dari kumpulan individu yang berpikiran sama dengan pengguna tersebut, kondisi ini akan semakin memperkuat opini yang dapat mempengaruhi perilaku politik (Leistert, 2015).

Rangkaian kritik kedua terhadap pandangan tekno-optimis sangat berkaitan erat dengan kebebasan sipil yang semakin melampaui konteks nasional. Sebagai contoh, kampanye gerakan sosial transnasional yang hanya terpusat di negaranegara kaya dan demokratis. Hari Aksi Global yang terjadi pada tanggal 15 Oktober 2011 dilaporkan mampu memobilisasi sekitar 2,5 juta pengunjuk rasa di 951 kota di 82 negara. Ledakan ini adalah puncak Gerakan Pendudukan. Beberapa laporan menempatkan episentrum aksi di Spanyol, yang menyumbang sekitar 1,25 juta demonstran, setengah dari total global. Para pengamat kemudian menyimpulkan bahwa peserta Hari Aksi Global sebagian besar adalah orang Eropa Barat dengan campuran peserta dari Amerika Utara. Kecuali Chili, hanya kelompok orang yang tersebar di Amerika Latin, kawasan Karibia, Eropa Timur, Afrika, Asia, dan Oseania yang mengambil bagian. Terlepas dari tren kebebasan sipil yang semakin mengglobal, perbedaan lintas negara mengisyaratkan bahwa faktor struktural yang terkait dengan konteks nasional terus mempengaruhi tingkat kebebasan sipil.

Penulis berpendapat bahwa setiap negara dicirikan oleh berbagai budaya keterlibatan politik. Akses ke komunikasi online mungkin dapat mengurangi perbedaan kesempatan untuk menyuarakan pendapat di tingkat nasional, tetapi tidak secara signifikan. Unjuk rasa bukanlah bentuk tindakan yang layak di semua negara. Tingkat kemakmuran perekonomian, ketimpangan ekonomi, dan demokrasi tidak hanya mempengaruhi tingkat keterlibatan warga negara tetapi juga jenis kegiatan dimana mereka berpartisipasi (Dalton et al., 2010). Lebih lanjut, terdapat proses dimana keluhan ekonomi dan politik pada tingkat individu dapat mempengaruhi keterlibatan sipil yang sangat bervariasi pada konteks nasional (Welzel \& Deutsch, 2012). Secara spesifik, keluhan ekonomi mampu diterjemahkan menjadi perbedaan perilaku politik di berbagai rezim politik (Uslaner \& Brown, 2005). Sementara itu, hubungan antara opini politik dan kebebasan sipil dimoderasi oleh lingkungan ekonomi di suatu negara (Dalton et al., 2010).

Berdasarkan kritik ini, sangat masuk akal apabila semakin banyak aktivis gerakan sosial yang menganggap diri mereka sebagai warga global (Tilly \& Wood, 2004). Mereka juga mampu mengembangkan program dan strategi politik yang melampaui batas-batas nasional. Aktivis tersebut menciptakan jaringan dan organisasi internasional yang terdiri dari kumpulan individu yang mempunyai pikiran yang sama untuk bertukar ide, saling membantu, dan mengkoordinasikan kegiatan. Namun, aktivis tersebut mungkin merupakan proporsi yang relatif kecil dari orang-orang yang mengambil bagian dalam demonstrasi dan kegiatan gerakan sosial lainnya di seluruh dunia (Tilly \& Wood, 2004). Akibatnya, beberapa sifat yang dihipotesiskan terkait dengan protes global mungkin menghasilkan efek yang beragam, tergantung pada konteks nasional. Ketiadaan efek independen juga mampu mempengaruhi gerakan sosial saat faktor lain dikendalikan. 
Kami menyimpulkan bahwa penelitian hingga saat ini memberi gambaran yang beragam tentang sejauh mana atribut gerakan sosial berlaku bagi aktivis kontemporer di berbagai negara. Dalam tinjauan literatur terbaru tentang gerakan sosial dan teknologi informasi dan komunikasi, Fominaya dan Gillan (2017) menekankan kebutuhan akan penelitian yang bernuansa realitas empiris untuk menguji kebenaran dari masa depan digital. Tulisan ini setidaknya berusaha untuk berkontribusi pada tingkat empiris dalam menganalisa pengaruh teknologi dan komunikasi terhadap masyarakat.

\section{Motivasi dan Kapasitas Untuk Terlibat Dalam Gerakan Sosial di Era Digital}

Pergeseran pada media baru atau Internet telah berubah dari komunikasi satu individu ke berbagai individu menjadi komunikasi dari berbagai individu ke berbagai individu lainnya. Kondisi ini memberikan dukungan bermacam arah dalam bentuk partisipasi dan heterogenitas konten, serta praktik komunikasi (Carpentier, 2011). Di Indonesia, media baru mengalami perkembangan keterlibatan politik, yang tidak hanya berfokus pada media baru yang praktis, tetapi juga memberikan penekanan lebih pada interaktivitas dan kreativitas daripada saluran media tradisional. Kondisi ini ditunjang oleh risiko rendah dalam melakukan mobilisasi sosial (Weiss, 2014). Oleh karenanya, peran Internet menjadi sangat penting guna mendukung keterlibatan sipil.

Norris (2001) mengembangkan model keterlibatan Internet yang mencakup tiga tingkat analisis. Pertama, ada konteks nasional, yang mencakup teknologi tingkat makro, sosial ekonomi, dan lingkungan politik, yang menentukan penyebaran Internet di setiap negara. Kedua, ada konteks kelembagaan dari sistem politik online, yang menawarkan struktur peluang yang memediasi antara warga dan pemerintah, termasuk penggunaan teknologi media digital oleh pemerintah dan masyarakat sipil. Terakhir, ada tingkat motivasi dan sumber daya individu, yang menentukan siapa yang berpartisipasi dalam sistem politik virtual (Norris, 2001).

Setiap warga negara memiliki peluang untuk berpartisipasi dalam kehidupan publik melalui Internet atau media digital. Norris menjelaskan bahwa peluang ini ditentukan oleh dua faktor, yakni: motivasi dan sumber daya (Norris, 2001). Motivasi menekankan pentingnya akses dan penggunaan Internet, termasuk kepercayaan, minat dan pengetahuan masyarakat yang membawa mereka pada proses partisipasi politik dan juga sikap berpikiran terbuka dalam mempercayai dan memuaskan proses demokrasi. Sementara itu, sumber daya menjelaskan atribut dan kapasitas individu dalam kehidupan publik, termasuk ekonomi (pendapatan rumah tangga), pendidikan (kapasitas penggunaan teknologi digital), dan pekerjaan (jenis pekerjaan atau jabatan). Ketiga prediktor ini dapat mempengaruhi akses ke teknologi digital. Dalam berbagai studi tentang bentuk partisipasi tradisional, pendidikan telah menjadi alat yang ampuh untuk meningkatkan partisipasi di antara orang-orang yang menjadi anggota partai atau pemilih pemilu.

Beberapa pengamat telah menganalisis motivasi kaum muda untuk berpartisipasi dalam aksi politik dan sipil (Banaji \& Buckingham, 2013). Motivasi kaum muda untuk berpartisipasi dalam kegiatan kemasyarakatan dapat didiskusikan dari perasaan internal yang dapat timbul dari mengambil bagian, rasa solidaritas 
kelompok, atau mencoba yang terbaik untuk mengatur kegiatan. Lebih lanjut, penelitian yang dilakukan oleh Banaji dan Buckingham (2013) menemukan bahwa kebebasan sipil di kalangan anak muda sangat berkaitan dengan identitas individu dan kelompok, yang didasari pada bahasa, musik, keyakinan politik, ras, agama, dan seksualitas. Selain itu, kebebasan tersebut sering didasarkan pada rasa ketidaksetaraan, diskriminasi, atau kemunafikan yang terkait dengan permasalahan di tingkat lokal, nasional, atau internasional. Hal ini memperkuat penelitian Carpini (2000) bahwa motivasi remaja untuk berpartisipasi muncul dari beberapa faktor, seperti tanggung jawab untuk bertindak, kepuasan dari keterlibatan dalam partisipasi publik untuk tujuan bersama, identifikasi masalah publik yang mempengaruhi komunitas, dan keyakinan bahwa mereka dapat membuat perbedaan.

Carpentier (2011) mengangkat fungsi pendidikan dengan menjelaskan dua hal yang berkaitan dengan demokrasi dan partisipasi. Pertama, nilai-nilai intrinsik seperti penyelenggaraan demokrasi yang dianggap sebagai komponen penting dari pengetahuan, serta praksis warga negara dimanfaatkan dan diekspresikan melalui proses partisipatif. Suara warga yang bersifat mayoritas mewakili keragaman yang lebih besar karena menjadi jaminan yang lebih baik untuk pengambilan keputusan yang baik (Carpini, 2000). Kedua, komponen pendidikan seperti pelaksanaan demokrasi atas partisipasi menghasilkan proses pembelajaran yang dapat memperkuat identitas kewarganegaraan, mirip dengan instrumen pendidikan untuk menciptakan warga negara yang lebih baik (Carpentier, 2011).

Salah satu alat yang ampuh untuk memobilisasi, mendidik, dan memotivasi kaum muda untuk terlibat dalam partisipasi politik adalah pendidikan politik (Edwards et al., 2013). Pendidikan kewarganegaraan akan mendorong keterlibatan politik yang lebih besar dan memungkinkan adanya hubungan antara politik informal dan formal, karena politik sekarang tidak ada dalam pendidikan kewarganegaraan. Tiga dimensi yang berbeda untuk memahami keterlibatan sipil dan politik, seperti pengetahuan politik (apa yang dipelajari individu tentang urusan publik), kepercayaan politik (orientasi publik untuk mendukung sistem politik dan para aktornya), dan partisipasi politik (kegiatan konvensional dan non-konvensional yang dirancang untuk mempengaruhi pemerintah dan proses pengambilan keputusan) (Norris, 2001).

Partisipasi politik selalu menjadi faktor penting dalam demokrasi klasik, demokrasi republik, demokrasi liberal, dan demokrasi partisipatoris karena mendorong keberhasilan politik, kepedulian publik, dan pembentukan warga negara yang berpendidikan (Poletta, 2014). Ini juga melibatkan proses pengambilan keputusan. Dalam konteks Indonesia, media digital telah memberikan berbagai peluang partisipasi bagi setiap warga negara yang ingin berkontribusi pada demokrasi Indonesia. Sejatinya, masyarakat dapat terlibat dalam kepentingan politik, seperti menggelar aksi massa dan melakukan pemantauan pemilu. Kondisi ini pada akhirnya dapat mengakomodir ranah kebebasan berekspresi pada setiap penduduk (Jurriens \& Tapsell, 2017). Sebagai contoh adalah kampanye yang mentargetkan para pemimpin politik dan organisasi pemerintahan yang berpengaruh seperti Save Ahok, \#Shame OnYouSBY, \#Save KPK, dan Kawal Pemilu. Selain itu, media digital telah digunakan untuk kepentingan sipil, seperti Internet Sehat, 
Jalin Merapi, \#support FEBRY, petisi online yang tertuang dalam situs Change.org untuk pembubaran FPI (Front Pembela Islam), dan juga Koin untuk Prita (Lim, 2013).

Era media digital meningkatkan peluang budaya partisipatif, konsumsi politik, dan keterlibatan sipil (Polletta, 2014). Dalam studi tentang anak muda di Indonesia, Ramli (2012) menjelaskan bahwa budaya partisipatif dalam politik mendukung empat hal. Pertama, peningkatan nilai-nilai demokrasi seperti keterbukaan, konsensus, dan akuntabilitas. Kedua, mendukung pengembangan keterampilan kewarganegaraan dengan menawarkan informasi politik daripada pemecahan masalah bagi pemuda. Ketiga, warga negara dapat menggunakan Internet untuk mengarahkan dan mengelola mobilisasi politik. Dan, terakhir, Internet dapat mendorong politik yang lebih progresif. Di Indonesia, keempat kepedulian tersebut relevan dengan gerakan Save KPK, dimana media sosial digunakan untuk menginformasikan dan memobilisasi masyarakat untuk memerangi korupsi dan mendukung lembaga anti korupsi (Clough, 2015).

\section{Menguji Kebebasan Sipil Menurut Perspektif Manuel Castells}

Untuk menguji sejauh mana kebebasan sipil memiliki kesamaan karakteristik dengan aktivis sipil, kami mengoperasionalkan beberapa aspek teori yang dikemukakan oleh Manuel Castells (Castells, 2012). Kami fokus pada teori Castells karena pendapatnya tentang gerakan sosial paling jelas diartikulasikan di era Internet, dan Castells adalah salah satu tokoh yang paling berpengaruh dalam teori komunikasi dan gerakan sosial.

Disamping itu, banyak analis gerakan sosial mendapatkan inspirasi pemikiran dari Castells. Pada dasarnya, mereka setuju dengan argument yang dibangun oleh Castells (Della Porta \& Mosca, 2005; Bennett et al., 2014). Karena keterbatasan data sekunder pada komponen-komponen yang membentuk kebebasan sipil (sebagai contoh, kebebasan berpendapat serta kebebasan berserikat dan berkumpul), kami fokus pada dimensi kebebasan sipil secara umum guna merepresentasikan variabel gerakan sosial di era digital.

Castells (2012) mengidentifikasi tiga faktor yang mempengaruhi kecenderungan individu untuk bergabung dalam gerakan sosial di era Internet. Dia mengklaim bahwa individu lebih mungkin untuk mengambil bagian dalam gerakan sosial jika mereka merasa dirugikan, bersedia untuk bergabung, dan terhubung secara digital.

Menurut Castells (2012), individu dapat mengekspresikan kemarahan ketika mereka melihat ketidakadilan dan mampu mengidentifikasi sumbernya. Pada keadaan tertentu, hal ini memungkinkan mereka untuk mengatasi ketakutan akan pembalasan di kemudian hari. Disamping itu, mereka dapat mengembangkan antusiasme dan harapan akan keadilan (Castells, 2012). Berdasarkan berbagai pertimbangan, kami mengambil hipotesis pertama, yakni:

H1: Individu dengan keluhan paling intens akan meningkatkan gerakan sosial.

Pada prinsipnya, kemampuan individu dalam melihat ketidakadilan, mengatasi rasa takut, dan terlibat dalam tindakan korektif tidak dapat 
didistribusikan secara acak. Beberapa kategori penduduk lebih rentan untuk melakukan hal tersebut daripada kategori penduduk yang lain. Pada kondisi ini, mereka relatif tersedia untuk melaksanakan gerakan sosial.

Menurut Castells (2012), kategori penduduk yang paling banyak tersedia dalam kegiatan gerakan sosial adalah individu yang berpendidikan tinggi, terutama dari kalangan pelajar dan professional. Terlebih jika individu tersebut menganggur dan memiliki ikatan kuat yang sudah ada sebelumnya dengan organisasi sipil. Ikatan semacam itu dapat menunjukkan rasa tanggung jawab sosial yang relatif tinggi dan meningkatkan kecenderungan bahwa teman dan kenalan yang berpikiran sama akan membantu menarik mereka ke dalam kegiatan gerakan sosial (Castells, 2012). Oleh karenanya, hipotesis kedua kami adalah sebagai berikut:

$\mathrm{H} 2$ : Individu yang berpendidikan tinggi, terutama mereka yang menganggur dan memiliki afiliasi kuat yang sudah ada sebelumnya dengan organisasi sipil, akan terlibat dalam gerakan sosial.

Menurut Castells, keluhan dan ketersediaan dapat diubah menjadi gerakan sosial hanya jika ada proses komunikasi yang memungkinkan individu menyebarluaskan rasa ketidakadilan mereka, berinteraksi dengan orang senasib yang merasa dirugikan, mengembangkan identitas kolektif, mampu menganalisis tentang penyebab dan solusi atas ketidakadilan yang dirasakan, dan merencanakan tindakan sosial kolektif yang sesuai. Untuk gerakan sosial kontemporer, Internet dan perangkat komunikasi nirkabel lainnya sangat penting dalam hal ini (Castells, 2012). Hipotesis ketiga kami adalah sebagai berikut:

H3: Kegiatan gerakan sosial akan meningkat jika individu sering menggunakan Internet dan media digital lainnya, serta apabila individu mampu merencanakan tindakan sosial kolektif dengan memanfaatkan Internet dan media digital lainnya.

\section{METODE}

Penelitian ini menggunakan metode kuantitatif dengan teknik analisa data sekunder (Creswell, 2013). Menurut Johnston (2014), tahapan penelitian dimulai dengan penyelidikan untuk mempelajari apa yang sudah diketahui dan apa yang masih harus dipelajari tentang suatu topik melalui peninjauan sumber-sumber sekunder dan penyelidikan yang sebelumnya telah dilakukan orang lain pada bidang tertentu.

Analisis data sekunder kemudian mengambil satu langkah lebih jauh, termasuk tinjauan data yang dikumpulkan sebelumnya pada bidang yang diminati (Johnston, 2014). Oleh karenanya, analisis data sekunder adalah pendekatan yang fleksibel dan dapat digunakan dalam beberapa cara. Analisis ini juga merupakan latihan empiris dengan langkah-langkah prosedural dan evaluatif, seperti halnya dalam mengumpulkan dan mengevaluasi data primer. Akan tetapi, analisis data sekunder tetap menjadi teknik penelitian yang kurang digunakan di beberapa bidang, termasuk komunikasi (Johnston, 2014). 
Adapun data sekunder yang digunakan oleh penulis dalam penelitian ini berasal dari Badan Pusat Statistik (BPS). Pada variabel kebebasan sipil, kami menggunakan data sekunder yang berasal dari Indeks Demokrasi Indonesia (IDI) yang dikompilasi oleh BPS pada periode 2015-2019 di 34 provinsi. Skala pengukuran kebebasan sipil berada pada rentang nilai 0 sampai dengan 100, dimana angka 0 menunjukkan ketiadaan kebebasan sipil dan 100 menunjukkan kesempurnaan kebebasan sipil. Sementara itu, pada variabel kepercayaan, afiliasi, dan tindakan kolektif, penulis memanfaatkan data sekunder yang berasal dari Survei Sosial dan Ekonomi Nasional (SUSENAS) yang dikompilasi oleh BPS pada periode 2015 -2019 di 34 provinsi.

Seperti halnya kebebasan sipil, skala pengukuran ketiga variabel berada pada rentang nilai 0 sampai dengan 100, dimana 0 menggambarkan tingkat terendah dan 100 menggambarkan tingkat tertinggi dari masing-masing komponen pembentuk modal sosial. Penulis juga menggunakan data sekunder dari BPS untuk menjelaskan persentase jumlah penduduk yang menggunakan internet dan capaian kebahagiaan pada periode 2015-2019 di 34 provinsi. Disamping itu kami mengoptimalkan data BPS untuk menganalisa karakteristik sosial ekonomi masyarakat melalui tingkat pengangguran dan rerata lama sekolah.

Tabel 1 menunjukkan ringkasan statistik dari variabel yang digunakan dalam tulisan ini. Kebebasan sipil secara rata-rata berada pada kategori yang relatif cukup baik, yakni 83 poin. Sementara itu, rerata persentase individu yang menggunakan Internet mencapai $31 \%$. Hanya saja, rerata komponen-komponen pembentuk modal sosial seperti kepercayaan, tindakan kolektif, dan jaringan berada dalam kondisi yang cukup buruk, yakni masing-masing mencapai 55, 52, dan 34 poin. Lebih lanjut, individu di Indonesia secara rata-rata relatif cukup bahagia (70 poin), dengan tingkat pengangguran dan rerata lama sekolah yang relatif berada pada level moderat.

Tabel 1: Ringkasan Statistik

\begin{tabular}{|l|c|c|c|c|c|}
\hline \multicolumn{1}{|c|}{ Variabel } & Observasi & Rerata & $\begin{array}{c}\text { Standar } \\
\text { Deviasi }\end{array}$ & $\begin{array}{c}\text { Nilai } \\
\text { Minimum }\end{array}$ & $\begin{array}{c}\text { Nilai } \\
\text { Maksimum }\end{array}$ \\
\hline Kebebasan Sipil & 170 & 82,69 & 10,51 & 51,01 & 100 \\
\hline Internet & 170 & 31,46 & 12,65 & 8,98 & 73,46 \\
\hline Percaya (Trust) & 170 & 55,26 & 3,41 & 36,20 & 61,07 \\
\hline Tindakan Kolektif & 170 & 51,89 & 4,36 & 32,64 & 61,20 \\
\hline Afiliasi & 170 & 34,02 & 4,68 & 20,70 & 48,64 \\
\hline Kebahagiaan & 170 & 70,39 & 2,53 & 60,97 & 87,77 \\
\hline Rata lama sekolah & 170 & 8,73 & 0,88 & 6,27 & 11,11 \\
\hline Pengangguran & 170 & 5,14 & 1,82 & 1,37 & 9,93 \\
\hline
\end{tabular}

Secara umum, guna menyelidiki hubungan antara internet dan kebebasan sipil di 34 provinsi, kami menggunakan model regresi linier berganda, dimana: Kebebasan Sipil $_{i}=\beta_{0}+\beta_{1}$ Internet $_{i}+\beta_{2}$ Percaya $_{i}+\beta_{3}$ Tindakan Kolektif $_{i}+\beta_{4}$ Afiliasi $_{i}$ $+\beta_{5}$ Kebahagiaan $_{i}+\beta_{6}$ Rerata Lama Sekolah $_{i}+\beta_{7}$ Pengangguran $_{i}+u_{i}$ 
Pada persamaan (1), terlihat bahwa $\beta_{1}, \beta_{2}, \beta_{3}, \beta_{4}, \beta_{5}, \beta_{6}$, dan $\beta_{7}$ adalah nilai koefisien dari variabel independen. Sementara itu, $\beta_{0}$ dan $u_{i}$ masing-masing menggambarkan konstanta dan tingkat kesalahan dari model. Nilai koefisien dari $\beta_{1}$ dan $\beta_{3}$ nantinya akan menjawab hipotesis 3 . Sementara itu, nilai koefisien dari $\beta_{4}, \beta_{6}$, dan $\beta_{7}$ akan menjawab hipotesis 2. Sedangkan, nilai koefisien dari $\beta_{2}$ dan $\beta_{5}$ akan menjawab hipotesis 1 .

Secara sederhana, kami mencoba menyelidiki korelasi antara kebebasan sipil dan masing-masing variabel bebas. Grafik 1 menunjukkan bahwa terdapat hubungan positif antara Internet dan kebebasan sipil. Kondisi serupa juga terjadi pada variabel kepercayaan, jaringan, rerata lama sekolah, dan kebahagiaan. Sementara itu, kondisi sebaliknya ditemui ketika tindakan kolektif dan pengangguran berinteraksi dengan kebebasan sipil, dimana terdapat korelasi negatif antar ketiga variabel ini. Pengukuran korelasi pada dasarnya tidak mampu melihat besaran koefisien dari variabel bebas. Sehingga, interpretasi nilai sangat sulit untuk dilakukan.

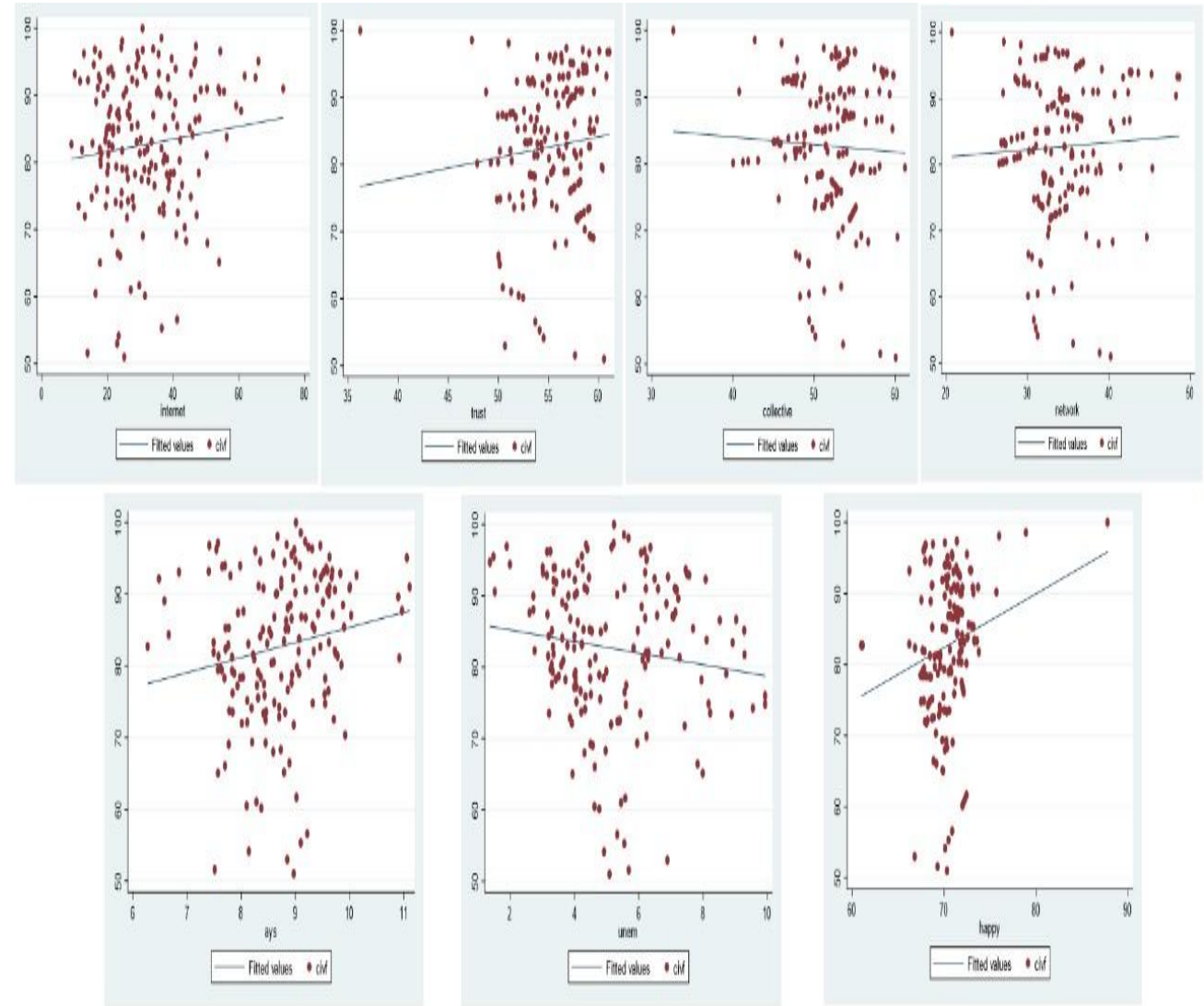

Grafik 1: Korelasi antara Kebebasan Sipil dan Variabel Independen 


\section{HASIL DAN PEMBAHASAN}

Tabel 2 menjelaskan dinamika hubungan antara Internet dan kebebasan sipil di Indonesia. Pada model 1, kami melakukan sebuah regresi sederhana dimana Internet berpengaruh secara positif dan signifikan terhadap kebebasan sipil. Satu (1) persen kenaikan Internet akan meningkatkan nilai kebebasan sipil sebesar 0,09 poin dengan menjaga variabel lain konstan. Meskipun model (1) ini valid yang ditunjukkan dengan $p$-value yang signifikan, akan tetapi koefisien $\mathrm{R}^{2}$ menunjukkan bahwa variabel independen hanya mampu menjelaskan 1 persen variasi pada model (1). Sementara itu, pada model 2, kami hanya memasukkan beberapa variabel independen ke dalam model. Variasi yang dijelaskan oleh variabel bebas pada model (2) relatif cukup baik, yakni mencapai 13 persen. Lebih lanjut, model (2) secara keseluruhan dinyatakan valid. Namun, variabel internet berubah menjadi tidak signifikan terhadap kebebasan sipil, meskipun terdapat hubungan positif antar keduanya.

Beralih ke model (3), kami menggunakan seluruh variabel bebas ke persamaan. Seperti halnya model (1) dan (2), model secara keseluruhan dinyatakan valid dan variasi yang dijelaskan oleh variabel independen mengalami peningkatan, yakni mencapai 18 persen. Pada hipotesis (1), keluhan-keluhan (grievances) yang ditandai dengan rendahnya kepercayaan dan kebahagiaan pada masyarakat seharusnya mampu meningkatkan gerakan sosial dan atau kebebasan sipil. Namun, pada konteks Indonesia, kepercayaan dan kebahagiaan berhubungan positif dan signifikan dengan kebebasan sipil. Lebih lanjut, 1 poin peningkatan pada kepercayaan dan kebahagiaan akan meningkatkan kebebasan sipil masing-masing sebesar 1 dan 0,8 poin dengan menjaga variabel lain konstan.

Seperti klaim Castells (2012), individu yang mempercayai pemerintahan dan bahagia mungkin mempunyai kecenderungan untuk tidak melakukan protes karena mereka memiliki tingkat keluhan politik yang relatif rendah dan oleh karena itu, cenderung percaya bahwa pemerintah bertindak untuk kepentingan seluruh penduduk. Akan tetapi, penulis berpendapat bahwa pandangan dari Castells mungkin sangat relevan dengan studi lintas negara.

Pada konteks studi di sebuah negara, kepercayaan yang tinggi dapat mendorong partisipasi individu dalam gerakan sosial. Coleman (1990) mengemukakan bahwa sebuah kelompok yang anggotanya mampu mewujudkan kepercayaan dan menempatkan kepercayaan yang luas satu sama lain akan lebih mencapai tujuan daripada kelompok sebanding yang tidak memiliki kepercayaan. Selain itu, individu yang percaya dan mampu membuat perkiraan tentang kesuksesan dalam gerakan sosial akan lebih percaya diri daripada orang yang tidak percaya, karena kepercayaan memungkinkan mereka untuk membentuk ekspektasi tentang tindakan orang lain (Dasgupta, 1988). Seperti yang ditunjukkan Yamagishi dan Yamagishi (1994) bahwa kepercayaan memberikan solusi untuk masalah yang disebabkan oleh ketidakpastian sosial.

Berpindah pada aspek kebahagiaan, Veenhoven (1988) menyatakan bahwa ketika warga negara mencapai tingkat kepuasan hidup yang diinginkan, mereka mungkin mulai semakin mencari kepuasan pribadi dan kesejahteraan materi, serta semakin berupaya untuk mengatasi masalah masyarakat yang lebih luas melalui 
keterlibatan politik. Kerangka teoritis ini secara umum konsisten dengan penelitian empiris yang menemukan bahwa warga yang lebih bahagia lebih peduli dengan masalah sosial dan politik secara umum. Ketika seseorang percaya bahwa kesejahteraan telah terjamin, individu yang lebih puas dengan kehidupan akan mulai melihat ke luar dan melampaui utilitas pribadi mereka sendiri dengan berpartisipasi lebih aktif dalam proses politik baik dalam bentuk konvensional (misalnya: voting) dan tidak konvensional (seperti: protes).

Tabel 2: Hasil Regresi Persamaan Kebebasan Sipil ${ }^{1}$

\begin{tabular}{|l|c|c|c|}
\hline \multirow{2}{*}{ Variabel Independen } & \multicolumn{3}{|c|}{ Variabel Dependen: Kebebasan Sipil } \\
\cline { 2 - 4 } & Model (1) & Model (2) & Model (3) \\
\hline Internet & $0,09^{*}$ & 0,05 & 0,05 \\
& $(0,06)$ & $(0,06)$ & $(0,07)$ \\
\hline Percaya (Trust) & & $1,11^{* * *}$ & $1,02^{* * *}$ \\
& & $(0,32)$ & $(0,30)$ \\
\hline Tindakan Kolektif & & $-1,42^{* * *}$ & $-1,18^{* *}$ \\
& & $(0,46)$ & $(0,48)$ \\
\hline Afiliasi & & $0,92^{* * *}$ & $0,69^{*}$ \\
& & $(0,36)$ & $(0,38)$ \\
\hline Kebahagiaan & & $0,85^{* * *}$ & $0,76^{* *}$ \\
& & $(0,30)$ & $(0,31)$ \\
\hline Rerata lama sekolah & & & $3,16^{* * *}$ \\
& & & $(1,12)$ \\
\hline Pengangguran & & & $-1,33^{* * *}$ \\
& & 170 & 170 \\
\hline Jumlah observasi & 170 & $0,35)$ \\
\hline Prob > F ( $p$-value $)$ & $0,10^{*}$ & $0002^{* * *}$ & $0,000^{* * *}$ \\
\hline $\mathrm{R}^{2}$ & 0,01 & 0,13 & 0,18 \\
\hline
\end{tabular}

Pada hipotesis (2), menurut Castells (2012), hanya beberapa orang yang bersedia untuk terlibat dalam gerakan sosial. Dalam pandangannya, individu yang berpendidikan, pengangguran, dan yang memiliki hubungan kuat dengan organisasi masyarakat sipil kemungkinan besar akan bersedia mengikuti gerakan sosial di era digital. Sehubungan dengan hal ini, kami menemukan beberapa dukungan untuk teori Castells. Individu yang mempunyai kedekatan kuat dengan organisasi masyarakat sipil berhubungan secara positif dan signifikan dengan kebebasan sipil. Jelasnya, satu poin kenaikan pada variabel afiliasi akan meningkatkan kebebasan sipil sebesar 0,69 dengan menjaga variabel lain konstan. Lebih lanjut, individu yang berpendidikan, direfleksikan oleh rerata lama sekolah yang tinggi, akan

\footnotetext{
1 Angka yang didalam kurung adalah robust standard of error. Tanda bintang dapat dijelaskan sebagai berikut: *** signifikan pada level 1 persen; $* *$ signifikan pada level 5 persen; * signifikan pada level 10 persen.
} 
berpartisipasi dalam gerakan sosial. Kondisi ini menunjukkan bahwa tambahan 1 poin pada variabel rata-rata lama sekolah akan meningkatkan kebebasan sipil sebesar 3,16 poin dengan menjaga variabel lain konstan.

Sebaliknya, penulis menemukan bahwa tingkat pengangguran yang tinggi berpengaruh secara signifikan terhadap kebebasan sipil di Indonesia. Jelasnya, kenaikan 1 persen tingkat pengangguran akan menyebabkan penurunan nilai kebebasan sipil sebesar 1,33 poin dengan menjaga variabel lain konstan. Paasonen (2020) mengaitkan fenomena pengangguran pada periode Arab Spring dengan kebebasan sipil. Dia menemukan bahwa para penganggur cenderung tidak berpartisipasi dalam gerakan sosial. Analisis lebih lanjut mengungkapkan bahwa mereka pada dasarnya kurang puas dengan kehidupan, namun tidak terlalu tertarik pada politik. Pada gilirannya, ketidakpuasan dengan kehidupan tidak mempengaruhi kemungkinan pemberontakan, tetapi mereka yang tertarik pada politik adalah pengunjuk rasa yang jauh lebih aktif. Secara keseluruhan, hasil menunjukkan bahwa pengangguran menyebabkan ketidakbahagiaan, tetapi karena rendahnya minat mereka terhadap politik, ketidakpuasan ini tidak mendorong mereka untuk turun ke jalan.

Beralih ke hipotesis (3), temuan kami tidak konsisten dengan pendapat Castells (2012). Penggunaan media komunikasi digital dapat meningkatkan kebebasan sipil akan tetapi hubungan ini tidak signifikan. Internet juga mampu menghubungkan warga yang tidak terhubung dan memungkinkan mereka untuk bertukar ide, menghargai kemampuan kolektif mereka, dan merencanakan aksi politik bersama. Sayangnya, data kami tidak memungkinkan untuk mengatakan apakah responden yang sering menggunakan media komunikasi digital cenderung terpengaruh dengan cara ini atau untuk menentukan mekanisme komunikasi online yang mendorong kebebasan sipil antar pengguna.

Sementara itu, tindakan kolektif berhubungan negatif dan signifikan dengan kebebasan sipil, dimana tambahan 1 poin pada aksi kolektif akan menurunkan kebebasan sipil sebesar 1,2 poin dengan menjaga variabel lain konstan. Penelitian dari Back et al. (2018) menunjukkan bahwa individu dengan kepedulian sosial yang tinggi (mempunyai ketakutan berlebih terhadap penolakan) lebih bersedia untuk berpartisipasi ketika mereka merasakan dukungan sosial yang tinggi dalam kelompok sosialnya.

Ini menunjukkan bahwa mereka berpartisipasi dalam gerakan sosial karena kesesuaian dengan grup. Sebaliknya, individu dengan tingkat keefektifitas hidup yang tinggi akan lebih bersedia untuk berpartisipasi ketika mereka memiliki dukungan sosial yang rendah. Kondisi ini menunjukkan bahwa mereka menganggap kebutuhan akan aktivitas gerakan sosial sebagai yang tertinggi ketika pendapat mereka tidak didukung. Mengacu pada logika ini, kami menduga bahwa individu tidak menerima dukungan sosial yang tinggi ketika bergabung dalam sebuah kelompok sosial. Disamping, terdapat kemungkinan apabila seseorang dengan tingkat keefektivitas hidup yang tinggi menganggap kebutuhan akan gerakan sosial sebagai yang terendah.

Pada prinsipnya, Castells (2012) mengasumsikan bahwa aksi kolektif terjadi di luar jalur kelembagaan yang ditentukan. Di beberapa negara yang demokratis, 
setiap warga negara tahu bahwa ada pilihan layak selain berunjuk rasa untuk menyampaikan keprihatinan mereka kepada elit pemerintahan. Alternatif ini mungkin termasuk menghubungi anggota parlemen dan menyumbangkan uang ke partai oposisi. Strategi semacam itu paling mudah diakses oleh orang kaya (Uslaner \& Brown, 2005).

\section{SIMPULAN}

Penelitian ini bertujuan untuk menyelidiki pengaruh Internet terhadap kebebasan sipil di 34 provinsi pada periode 2015-2019. Penulis menguji secara empiris dimensi-dimensi gerakan sosial dari Manuel Castells (2012). Secara khusus, individu yang melakukan gerakan sosial di Indonesia adalah seseorang terpelajar yang memiliki ikatan yang kuat dengan asosiasi sipil. Berbeda dengan Castells, para penganggur di Indonesia cenderung tidak berpartisipasi dalam gerakan sosial. Literatur tentang partisipasi politik di era Internet umumnya optimis tentang kemampuan teknologi dan komunikasi melalui Internet untuk mendemokratisasi dan memperluas kebebasan sipil. Akan tetapi kami menemukan bahwa kebebasan sipil terus dikaitkan secara signifikan dengan beberapa hak sosial yang bersifat istimewa, sehingga menimbulkan pertanyaan tentang kemampuan Internet dalam menghilangkan hambatan sosial terhadap partisipasi sipil.

Temuan kami juga mempertanyakan kemampuan Internet dalam meningkatkan kebebasan sipil. Bertentangan dengan klaim Castells, tingkat kepercayaan yang tinggi dapat mendorong partisipasi individu dalam gerakan sosial. Juga, kami menduga bahwa individu tidak menerima dukungan sosial yang tinggi ketika bergabung dalam sebuah kelompok sosial. Disamping, terdapat kemungkinan apabila seseorang dengan tingkat keefektivitas hidup yang tinggi menganggap kebutuhan akan gerakan sosial sebagai yang terendah. Lebih lanjut, ketika individu mencapai tingkat kepuasan hidup yang diinginkan, mereka akan semakin mencari kepuasan pribadi dan kesejahteraan materi. Apabila individu telah mencapai tingkat optimal dari kepuasan pribadi dan kesejahteraan, maka dia akan berupaya untuk mengatasi masalah masyarakat yang lebih luas melalui keterlibatan politik.

\section{DAFTAR PUSTAKA}

Back, E.A., Back, H., \& Siven, D. (2018). Why Engage in Collective Action? The Conditional Effect of Social Support and Efficacy on Protest Participation. Basic and Applied Social Psychology, 40 (1), 49-59.

Baek, Y.M., Wojcieszak, M., \& Carpini, M.X.D. (2012). Online versus face-to-face deliberation: Who? Why? What? With what effects? New Media \& Society, 14(3), 363-383.

Banaji, S., \& Buckingham, D. (2013). The Civic Web: Young People, the Internet and Civic Participation. Boston, MA: The MIT Press 
Bennett, W., Segerberg, A., \& Walker, S. (2014). Organization in the crowd: Peer production in large-scale networked protests. Information, Communication \& Society, 17(2), 232-260.

Brym, R. (2007). Six lessons of suicide bombers. Contexts, 6 (4), 40-45.

Brym, R., Slavina, A., Todosijevic, M., \& Cowan, D. (2018). Social movement horizontality in the Internet age? a comment on Castells in light of the Trump victory. Canadian Review of Sociology, 55(4), 624-634.

Carpentier, N. (2011). Media and participation: A site of ideological-democratic struggle. Bristol, UK: Intellect Ltd.

Carpini, M.X.D. (2000). Gen.com: Youth, civic engagement, and the new information environment. Political Communication, 17(4), 341-349.

Castells, M. (2012). Networks of outrage and hope: Social movements in the internet age. Cambridge, UK: Polity.

Coleman, J. (1990). Foundations of Social Theory. Cambridge, MA: Harvard University Press.

Coyne, G. (2012). Shifting loyalties: Support for a global state and nationalism. Globalizations, 9(5), 713-724.

Creswell, J. (2013). Research Design: Qualitative, Quantitative, and Mixed Methods Approaches. Thousand Oaks, CA: Sage Publications, Inc.

Dalton, R., Van Sickle, A., \& Weldon, S. (2010). The individual-Institutional nexus of protest behaviour. British Journal of Political Science, 40 (1), 51-73.

Dasgupta, P. (1988). Trust as a Commodity. In D. Gambetta (Eds.), Trust: Making and Breaking Cooperative Relations (pp. 49-72). Oxford: Basil Blackwell.

Della Porta, D., \& Mosca, L. (2005). Global-net for global movements? A network of networks for a movement of movements. Journal of Public Policy, 25(1), $165-190$.

Edwards, F., Howard, P.N., \& Joyce, M. (2013). Digital activism and non-violent conflict, Digital Activism Research Project. Seattle: University of Washington.

Farrell, H. (2012). The consequences of the Internet for politics. Annual Review of Political Science, 15 (1), 35-52. 
Fominaya, C., \& Gillan, K. (2017). Navigating the technology-media-movements complex. Social Movement Studies, 16 (4), 383-402.

Hannigan, J.A. (1985). Alain Touraine, Manuel Castells and social movement theory: A critical appraisal. Sociological Quarterly, 26 (4), 435-454.

Haunss, S. (2015). Promise and practice in studies of social media and movements. In L. Dencik \& O. Leistert (Eds.), Critical perspectives on social media and protest: Between control and emancipation (pp. 13-31). London: Rowman \& Littlefield.

Johnston, M.P. (2014). Secondary Data Analysis: A Method of which the Time Has Come. Qualitative and Quantitative Methods in Library, 3, 619-626.

Jurriens, E., \& Tapsell, R. (2017). Challenges and opportunities of the digital 'revolution' in Indonesia. In E. Juriens \& R. Tapsell (Eds.), Digital Indonesia: Connectivity and Divergence (pp. 1-20). Singapore: ISEAS Yusof Ishak Institute.

Inglehart, R. (2018). Cultural evolution. Cambridge, UK: Cambridge University Press.

Leistert, O. (2015). The revolution will not be liked: On the systemic constraints of corporate social media platforms for protests. In L. Dencik \& O. Leistert (Eds.), Critical perspectives on social media and protest: Between control and emancipation (pp. 35-51). London: Rowman \& Littlefield.

Lim, M. (2013). Many Clicks but Little Sticks: Social Media Activism in Indonesia. Journal of Contemporary Asia, 43(4), 636-657.

McAdam, D., Tarrow, S., \& Tilly, C. (2009). Comparative perspectives on contentious politics. In M. Lichbach \& A. Zuckerman (Eds.), Comparative politics: rationality, culture and structure (pp. 260-290). Cambridge: Cambridge University Press.

Morozov, E. (2011). The net delusion: The dark side of internet freedom. New York: Public Affairs.

Norris, P. (2001). Digital divide: civic engagement, information poverty, and the internet worldwide. Cambridge, UK: Cambridge University Press.

Oser, J., Hooghe, M., \& Marien, S. (2013). Is online participation distinct from offline participation? A latent class analysis of participation types and their stratification. Political Research Quarterly, 66 (1), 91-101. 
Paasonen, K. (2020). Are the unhappy unemployed to blame for unrest? Scrutinising participation in the Arab Spring uprisings. Peace Economics, Peace Science, and Public Policy, 26 (1), 1-22.

Poletta, F. (2014). Participatory democracy's moment. Journal of International Affairs, 68 (1), 79-92.

Ramli, R. (2012). Youth political participation in Asia: Outlooks in Malaysia and Indonesia." In Youth: Future Agents of Change or Guardians of Establishment? Retrieved from http://www.kas.de/wf/doc/kas_32176-1522-230.pdf?120926051913 (accessed 20.09.2020).

Shirky, C. (2008). Here comes everybody: The power of organizing without organizations. New York: Penguin.

Tilly, C., \& Wood, L. (2004). Social movements, 1768-2012. London: Routledge.

Uslaner, E.M., \& Brown, M. (2005). Inequality, trust, and civic engagement. American Politics Research, 33(6), 868-894.

Van Laer, J., \& Van Aelst, P. (2010). Internet and social movement action repertoires: Opportunities and limitations. Information, Communication \& Society, 13(8), 1146-1171.

Veenhoven, R. (1988). The utility of happiness. Social Indicators Research, 20(4), 333-354.

Weiss, M. (2014). New media, new activism: Trends and trajectories in Malaysia, Singapore and Indonesia. International Development Planning Review, 36(1): 91-109.

Welzel, C., \& Deutsch, F. (2012). Emancipative values and non-violent protest: The importance of 'ecological' effects. British Journal of Political Science, 42(2), 465-479.

Yamagishi, T., \& Yamagishi, M. (1994). Trust and commitment in the United States and Japan. Motivation and Emotion, 18, 129-166.

Zhang, T., \& Brym, R. (2019). Tolerance of homosexuality in 88 countries: Education, political freedom and liberalism. Sociological Forum, 34(2), 501521. 